\title{
Pengelolaan DAS Kota Padang Berbasiskan Sistem Informasi Geografis
}

\section{Catchment Area Management Of Padang City Based On Geographic Information System}

\author{
Era Alfansyuri ${ }^{1)} \&$ Indra Farni $^{2)}$ \\ ${ }^{1)}$ Jurusan Teknik Sipil, Politeknik Negeri Padang, Kampus Unand Limau Manis Padang, \\ Telp. 0751-72590 Fax. 0751-72576. Email: eraalfansyuri@yahoo.com \\ 2) Jurusan Teknik Sipil, Universitas Bung Hatta
}

\section{ABSTRACT}

Changes in soil physical and socio-economic life of the people Padang City be the cause of a decrease the condition of the watershed (DAS). Catchment area management can be done through an assessment of the components of a watershed both spatial and attribute in a system that is comprehensive and and done with integrated management. Preparation of physical watershed data done by utilizing the technology of Geographic Information Systems (GIS) in which GIS has the ability to perform the presentation of data DAS and spatial analyzes to look at the ability of the DAS.

Keywords: Chatchment Area, physical data fields, attributes, Geographic Information Systems

\section{PENDAHULUAN}

Seiring dengan terjadinya perubahan kondisi alam dan lingkungan secara geomorfologi di Kota Padang baik meliputi kondisi geologi, kondisi tanah dan topografi yang menyebabkan sering terjadinya erosi, banjir, tanah longsor serta turunnya kemampuan daya dukung lahan seperti kekeringan. Selain itu faktor perubahan iklim juga menjadi penyebab terjadinya potensi terhadap kerusakan lahan dan wilayah. Kehidupan dan pergerakan ekonomi sosial masyarakat Kota Padang juga menjadi penyebab terjadinya penurunan (degradasi) kondisi daerah aliran sungai (DAS) seperti terjadinya pusat pemukiman yang baru, penebangan hutan, kebakaran hutan serta pemanfaatan lahan yang tidak sesuai dengan kaidah konservasi tanah dan air.

Permasalahan pengelolaan DAS dapat dilakukan melalui suatu pengkajian komponen-komponen DAS dan penelusuran hubungan antar komponen yang saling berkaitan, sehingga tindakan pengelolaan dan pengendalian yang dilakukan tidak hanya bersifat parsial dan sektoral, tetapi sudah terarah pada penyebab utama kerusakan dan akibat yang ditimbulkan, serta dilakukan dengan pengelolaan secara terpadu.

Seyhan (1977) dalam Gunawan dan Hartono (2000) menyebutkan bahwa karakteristik DAS dapat dikelompokkan menjadi dua kategori, yaitu adanya faktor lahan (topografi, tanah, geologi, dan geomorfologi); dan faktor vegetasi dan penggunaan lahan.

Penyediaan data dan informasi mengenai kondisi daerah aliran sungai sangat diperlukan terutama dalam menunjang strategi pengelolaan DAS yang berdayaguna terutama data-data fisik lahan secara spasial maupun beserta informasinya (atribut). Penyusunan data-data fisik DAS dilakukan dengan memanfaatkan teknologi Sistem Informasi Geografis (SIG) dimana SIG mempunyai kemampuan untuk melakukan penyajian data-data DAS dan analisa-analisa spasialnya untuk melihat kemampuan dari DAS itu sendiri.

Dengan pengelolaan DAS berbasiskan Sistem Informasi Geografis ini dimaksudkan untuk menghimpun semua data-data fisik DAS dalam suatu sistem yang terpadu 
sehingga dapat digunakan dalam melakukan analisa secara keruangan terhadap kondisi DAS tersebut.

Tujuan dari penelitian ini sendiri adalah sebagai berikut :

1. Tersedianya data spasial DAS sebagai dasar dalam pengelolaan DAS dalam Sistem Informasi Geografis

2. Melakukan analisa secara spasial terhadap kondisi fisik dan kependudukan dari masing-masing DAS Kota Padang

\section{Daerah Aliran Sungai (DAS)}

Daerah aliran sungai (DAS) adalah suatu wilayah yang dibatasi oleh punggung punggung bukit yang menampung air hujan dan mengalirkannya melalui saluran air, dan kemudian berkumpul menuju suatu muara sungai, laut, danau atau waduk. (Fahmudin Agus dan Widianto.2004). Pada daerah aliran sungai terdapat berbagai macam penggunaan lahan yang dikelola dan dimanfaatkan oleh masyarakat, misalnya hutan, lahan pertanian, pedesaan dan jalan, sehingga dengan demikian DAS mempunyai berbagai fungsi sehingga perlu dikelola.

Pengelolaan DAS merupakan suatu kegiatan yang dilakukan oleh masyarakat, petani dan pemerintah untuk memperbaiki keadaan lahan dan ketersediaan air secara terintegrasi di dalam suatu DAS.

Selanjutnya Daerah Aliran Sungai (DAS) merupakan satu kesatuan ekosistem yang unsur-unsur utamanya terdiri atas sumberdaya alam tanah, air dan vegetasi serta sumberdaya manusia sebagai pelaku pemanfaat sumberdaya alam tersebut. DAS di beberapa tempat di Indonesia memikul beban amat berat sehubungan dengan tingkat kepadatan penduduknya yang sangat tinggi dan pemanfaatan sumberdaya alamnya yang intensif sehingga terdapat indikasi belakangan ini bahwa kondisi DAS semakin menurun dengan indikasi meningkatnya kejadian tanah longsor, erosi dan sedimentasi, banjir, dan kekeringan. Disisi lain tuntutan terhadap kemampuannya dalam menunjang sistem kehidupan, baik masyarakat di bagian hulu maupun hilir demikian besarnya.

Sebagai suatu kesatuan tata air, DAS dipengaruhi kondisi bagian hulu khususnya kondisi biofisik daerah tangkapan dan daerah resapan air yang di banyak tempat rawan terhadap ancaman gangguan manusia. Hal ini mencerminkan bahwa kelestarian DAS ditentukan oleh pola perilaku, keadaan sosial-ekonomi dan tingkat pengelolaan yang sangat erat kaitannya dengan pengaturan kelembagaan (institutional arrangement).

Pendekatan secara menyeluruh terhadap perencanaan pengelolaan DAS sangat diperlukan dengan mempertimbangkan semua komponen sumberdaya alam yang meliputi faktor fisik lingkungan, social ekonomi, politik, dan tataguna lahan. Untuk dapat melakukan monitoring dan evaluasi dampak aktivitas pengelolaan DAS terhadap komponen komponen lingkungan, data fisik DAS dapat dimanfaatkan sebagai satu unit perencanaan dan evaluasi yang sistematis, logis, dan rasional. Perencanaan pengelolaan DAS secara menyeluruh diharapkan dapat memberikan manfaat secara multi-guna kepada para pihak - pihak yang berkepentingan.

\section{Pengertian Sistem Informasi Geografis}

Pada dasarnya, istilah Sistem Informasi Geografis (SIG) merupakan gabungan dari tiga unsur pokok yaitu : sistem, informasi, dan geografis. Istilah sistem dapat didefinisikan sebagai sekumpulan objek, ide berikut saling keterhubungannya (interrelasi) dalam mencapai tujuan atau sasaran bersama. Dan istilah geografis merupakan bagian dari spasial (keruangan) atau mengandung pengertian suatu persoalan mengenai bumi : permukaan dua atau tiga dimensi. Sedangkan informasi geografis mengandung pengertian informasi mengenai tempat-tempat yang terletak di permukaan bumi, pengetahuan mengenai posisi dimana suatu objek terletak di permukaan bumi, dan informasi mengenai keterangan-keterangan (atribut) yang terdapat di permukaan bumi yang posisinya diberikan atau diketahui. Jadi 
Sistem Informasi Geografis (SIG) merupakan suatu kesatuan formal yag terdiri dari berbagai sumber daya fisik dan logika yang berkenaan dengan objek-objek yang terdapat di permukaan bumi.

Sedang tugas utama yang mampu diselesaikan dengan SIG menurut Scholten dan Stillwell (1990), secara garis besar terdiri atas tiga tugas utama:

ß Menyimpan, mengorganisasikan, mengurus, dan mengintegrasikan data bereferensi geografis dalam jumlah yang banyak.

ß Menyediakan cara untuk memperolehanalisis dari hubungan khusus komponen data geografis. Teknik analisis yang dllakukan dapat secara sederhana atau lebih rumit. Analisis yang mendalam dijumpai saat pengenalan pemodelan.

¡ Melakukan pengorganisasian dan manajemen sejumlah besar data dalam satu jalur, sehingga pemakai mudah untuk mangakses informasi. Selain itu, SIG juga memberikan kemudahan bagi pengemaskinian (updating) data geografis (peta digital) dibanding secara manual/tradisional.

\section{METODOLOGI}

Dalam pengelolaan Das Kota Padang ini berbasiskan Sistem Informasi Geografis ini dilaksanakan dengan melakukan perolehan dan masukan data, pengelolaan data dan analisa serta penyajiannya. Perolehan data dan masukan data meliputi data-data Administrasi, data spasial DAS meliputi peta penggunaan lahan, peta DAS, peta jenis tanah, peta kemiringan dan data kependudukan. Selanjutnya pengelolaan data spasial dilakukan dengan melakukan konversi data spasial kedalam bentuk format digital dengan melakukan proses digitasi data spasial secara pemetaan digital, sedangkan pengelolaan data atribut dilakukan dengan pembuatan basis data dalam sistem informasi Geografis.
Secara umum dapat dilihat dari diagram alir berikut :

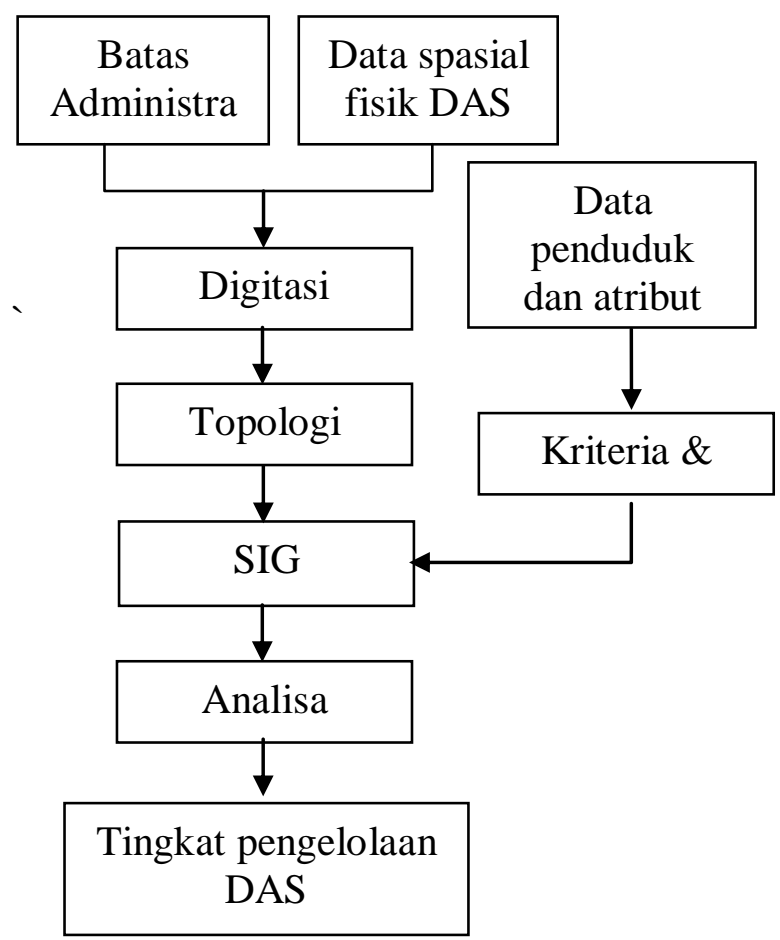

Gambar 1. Diagram alir metedologi penelitian

Untuk mendapatkan informasi sebagai dasar pengelolaan DAS maka dilakukan analisa secara spasial dengan memanfaatkan tools yang tersedia pada perangkat lunak GIS

\section{HASIL DAN PEMBAHASAN}

Dari proses pemetaan digital terhadap datadata spasial yang ada, yang kemudian dilanjutkan dengan pembuatan basisdata terhadap data spasial dan atributnya dengan menggunakan Sistem informasi geografis maka kita dapat melakukan analisa-analisa spasial terhadap data keruangan DAS Kota Padang, dengan memanfaatkan fasilitas identify dan Query.

\section{Daerah Aliran Sungai}

DAS yang masuk dalam wilayah administrasi Kota Padang meliputi 6 kawasan daerah aliran sungai yakni :

1. DAS Air Dingin $(12919,71 \mathrm{Ha})$

2. DAS Air Timbalun $(6778,83 \mathrm{Ha})$

3. DAS Batang Arau $(17713,86 \mathrm{Ha})$ 
4. DAS Batang Kandih $(6727,01 \mathrm{Ha})$

5. DAS Batang Kuranji $(22067,81 \mathrm{Ha})$

6. DAS Sungai Pisang $(2918,14 \mathrm{Ha})$

Tabel 1. Luas DAS tiap kecamatan

\begin{tabular}{llr}
\hline Nama & & \\
DAS & Kecamatan & luas (Ha) \\
\hline Air & Koto Tangah & 12694.56 \\
Dingin & Pauh & 225.13 \\
Air & Bungus Teluk & \\
Timbalun & Kabung & 5423.56 \\
& Lubuk Begalung & 514.62 \\
& Lubuk Kilangan & 840.62 \\
Batang & Kuranji & 375.43 \\
Arau & Lubuk Begalung & 2552.01 \\
& Lubuk Kilangan & 7578.48 \\
& Padang Barat & 538.76 \\
& Padang Selatan & 1269.50 \\
& Padang Timur & 860.95 \\
& Padang Utara & 184.30 \\
& Pauh & 4354.39 \\
Batang & Koto Tangah & 6726.99 \\
Kandih & Koto Tangah & 3601.85 \\
Batang & Kuranji & 4978.92 \\
Kuranji & Nanggalo & 876.14 \\
& Padang Barat & 2.59 \\
& Padang Utara & 646.88 \\
Pungai & Pauh & 11961.40 \\
& Kabung & 2918.10
\end{tabular}

Secara Administrasi, kawasan DAS berada pada wilayah administrasi Kota Padang yang terdiri atas 11 Kecamatan, berikut ini data luasan DAS untuk setiap kecamatan di Kota Padang.

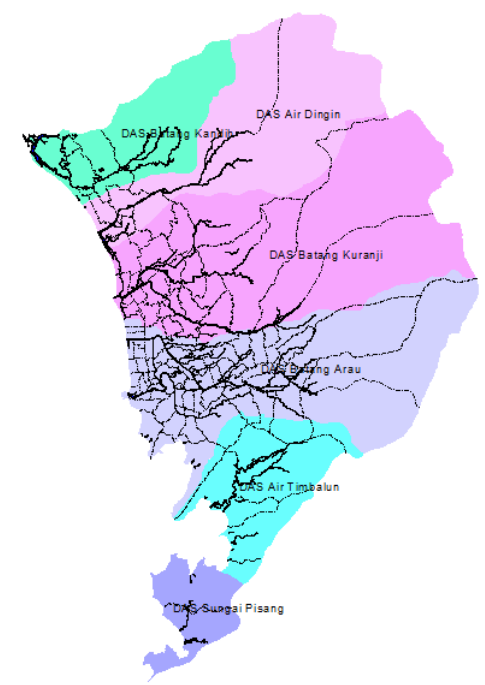

Gambar 2. DAS Kota Padang

\section{Kemiringan/Kelerengan}

Kemiringan lereng merupakan faktor lain yang mempengaruhi keadaan suatu DAS selain penggunaan lahan . Kondisi wilayah tersebut berpotensi mengalami erosi yang besar. Erosi akan meningkat apabila elreng semakin curam. Selain dari memperbesar jumlah aliran permukaan, semakin curamnya lereng juga memperbesar energi angkut air. Hal ini disebabkan gaya berat yang semakin besar sejalan dengan semakin miringnya permukaan tanah dari bidang horizontal, sehingga lapisan tanah atas yang tererosi akan semakin banyak.

Tabel 2. Luas Kelerengan tiap DAS

\begin{tabular}{|c|c|c|c|c|}
\hline & & $2-15$ & $15-$ & \\
\hline DAS & $0-2 \%$ & $\%$ & $40 \%$ & $>40 \%$ \\
\hline Air Dingin & 1382.97 & 930.39 & 3504.16 & 7102.19 \\
\hline Air Timbalun & 1077.21 & 0.00 & 1752.45 & 3948.80 \\
\hline Batang Arau & 5457.52 & 2564.51 & 3566.18 & 6124.82 \\
\hline Batang Kandih & 1939.79 & 1296.43 & 1966.12 & 1524.65 \\
\hline Batang Kuranji & 6239.62 & 690.21 & 2019.78 & 13118.20 \\
\hline
\end{tabular}




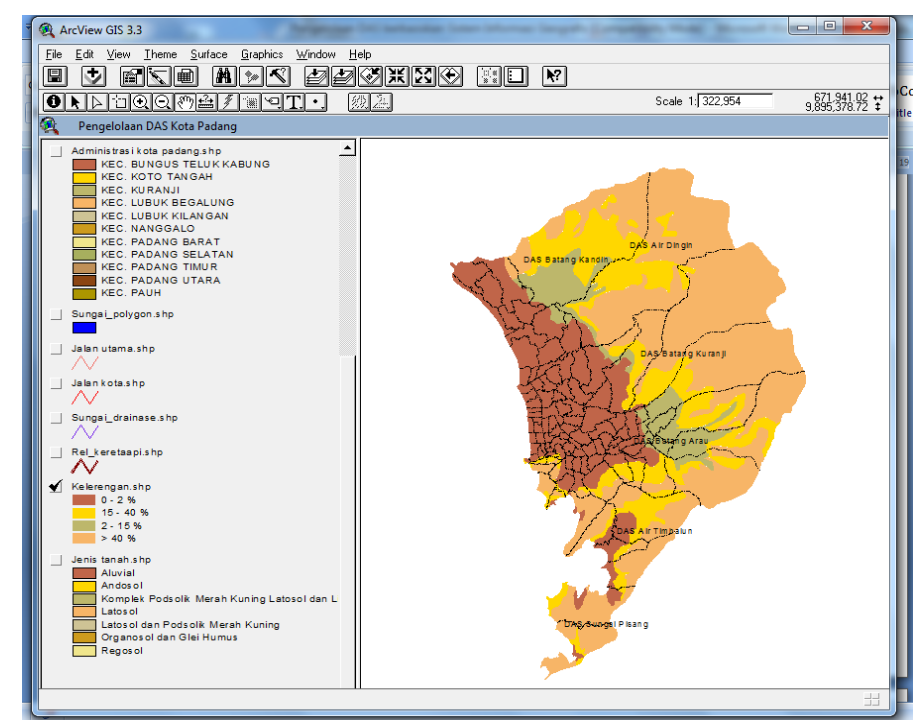

Gambar 3. Peta kemiringan Kota Padang

Dari aspek kemiringan Kota Padang terdiri dari empat pembagian kemiringan yakni, kemiringan 0-2\%, 2-15\%, 15-40\% dan besar dari $40 \%$. Selanjutnya di overlaykan dengan kawasan DAS Kota Padang sehingga diperoleh data luasan kemiringan untuk masing-masing DAS, seperti yang terlihat pada tabel 2 .

\section{Penggunaan lahan}

Penggunaan lahan sangat mempengaruhi aliran permukaan, erosi, dan sedimentasi terutama dalam hal kemampuan penggunaan lahan memberi sanggaan (buffer) terhadap masukan (input) curah hujan sehingga tidak menimbulkan erosi dan banjir akibat limpasan aliran permukaan.

Kemampuan menyangga dari suatu jenis penggunaan lahan dipengaruhi oleh struktur tajuk tanaman, sistem perakaran tanaman, dan kerapatan tanaman (Yuzirwan, 1996).

Tabel 3. Penggunaan lahan tiap DAS

\begin{tabular}{lrrrrrrr}
\hline Nama DAS & Hutan & Kebun & Ladang & $\begin{array}{c}\text { lahan } \\
\text { kosong }\end{array}$ & Permukiman & Sawah & $\begin{array}{r}\text { Semak/ } \\
\text { Belukar }\end{array}$ \\
\hline $\begin{array}{l}\text { Air Dingin } \\
\text { Air }\end{array}$ & 10879.92 & 70.56 & 17.74 & 29.46 & 1140.72 & 755.91 & 0.00 \\
$\begin{array}{l}\text { Timbalun } \\
\text { Batang }\end{array}$ & 5530.66 & 115.17 & 68.99 & 8.12 & 298.44 & 769.63 & 0.00 \\
$\begin{array}{l}\text { Arau } \\
\text { Batang }\end{array}$ & 9934.91 & 475.27 & 1.03 & 213.90 & 4504.14 & 2110.06 & 369.71 \\
$\begin{array}{l}\text { Kandih } \\
\text { Batang }\end{array}$ & 4122.93 & 714.03 & 152.15 & 52.32 & 1078.16 & 601.37 & 0.00 \\
& & & & & & &
\end{tabular}




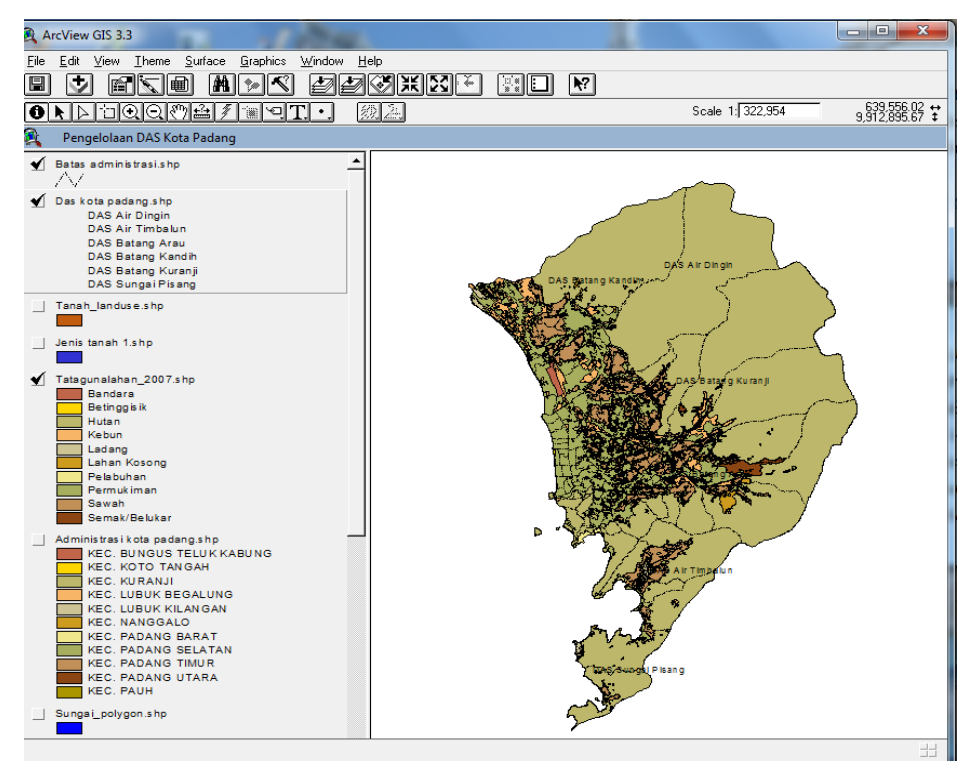

Gambar 4. Peta Penggunaan lahan Kota Padang

Sesuai dengan penggunaan lahan Kota kawasan DAS, seperti yang terlihat pada Padang maka diperoleh beberapa penggunaan lahan yang tediri dari, Betingistik, Hutan, Kebun, Ladang, Pelabuhan, Permukiman, Sawah dan Semak belukar. Berdasarkan analisa secara spasial dengan metode intersection pada geoprocessing wizard maka diperoleh gambaran penggunaan lahan untuk tiap-tiap tabel 3.

\section{Jenis tanah}

Lahan merupakan sumberdaya alam yang jumlahnya terbatas. Kebutuhan akan sumberdaya lahan oleh manusia yang semakin meningkat telah memberikan corak tersendiri terhadap pola penggunaan lahan di suatu kawasan. 


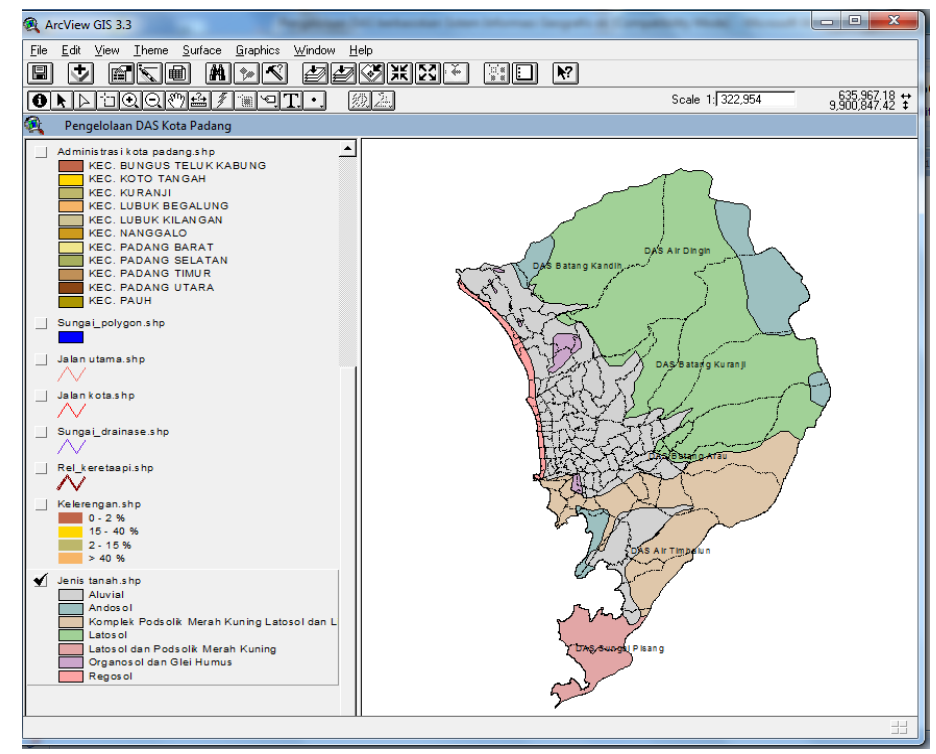

Gambar 5. Peta Jenis Tanah Kota Padang

Dampak yang ditimbulkan adalah terjadinya perubahan tata guna lahan, seperti perubahan pemanfaatan lahan dari hutan ke pertanian dan pemanfaatan lahan lainnya, yang dapat mengganggu stabilitas tata air dan tanah (Asdak, 2003).
Mengetahui jenis, karakter, penyebaran tanah di suatu wilayah akan sangat membantu karena dengan demikian dapat ditentukan beberapa hal sperti menentukan tujuan pemanfaatan tanah, apakah layak untuk pertanian atau lebih memiliki nilai pemanfaatan lain, misalnya untuk konservasi hutan atau wisata alam.

Tabel 4. Jenis tanah DAS

\begin{tabular}{lllccccc}
\hline \multirow{2}{*}{ No } & \multicolumn{1}{c}{ Jenis Tanah } & \multicolumn{7}{c}{ DAS (Ha) } \\
\cline { 3 - 8 } & & $\begin{array}{c}\text { Sungai } \\
\text { Pisang }\end{array}$ & $\begin{array}{c}\text { Batang } \\
\text { Kuranji }\end{array}$ & $\begin{array}{c}\text { Batang } \\
\text { Kandih }\end{array}$ & $\begin{array}{c}\text { Batang } \\
\text { Arau }\end{array}$ & $\begin{array}{c}\text { Air } \\
\text { Timbalun }\end{array}$ & $\begin{array}{c}\text { Air } \\
\text { Dingin }\end{array}$ \\
\hline 1 & Latosol & - & 12921 & 3947 & 5078 & - & 10334.26 \\
2 & Andosol & - & 2917 & 729 & 856 & 109.84 & 978.64 \\
3 & Aluvial & - & 5446 & 1802 & 5008 & 2209.29 & 1339.31 \\
4 & Regosol & - & 121 & 187 & 177 & - & 203.76 \\
5 & Organosol dan Glei Humus & - & 500 & 42 & 114 & - & 27.99 \\
& Latosol dan Podsolik Merah & & & & & & - \\
6 & Kuning & 2955 & - & - & - & 88.69 & - \\
& Komplek Podsolik Merah & & - & - & 6418 & 4346.00 & -
\end{tabular}

parameter dalam pengelolaan DAS tersebut maka selanjutnya dilakukan scoring terhadap masing-masing komponen parameter pengelolaan DAS tersebut meliputi kelerengan DAS, Jenis tanah, penggunaan lahan sertas data kependudukan 
Tabel 5. Scoring kelerengan

\begin{tabular}{ccc}
\hline No & Kelerengan & Scoring \\
\hline 1 & $0-2 \%$ & 1 \\
2 & $2-15 \%$ & 2 \\
3 & $15-40 \%$ & 3 \\
4 & $>40 \%$ & 4
\end{tabular}

Tabel 6. Scoring jenis tanah

\begin{tabular}{clc}
\hline $\mathrm{N}$ & Jenis tanah & Scoring \\
$\mathrm{o}$ & & \\
\hline 1 & Aluvial, Andosol & 4 \\
2 & $\begin{array}{l}\text { Regosol, Organosol } \\
\text { dang lei humus }\end{array}$ & 3 \\
3 & $\begin{array}{l}\text { Latosol, Latosol dan } \\
\text { podsolik merah kuning }\end{array}$ & 2 \\
4 & $\begin{array}{l}\text { Komplek Podsolik } \\
\text { Merah kuning latosol } \\
\text { dan litosol }\end{array}$ & 1 \\
\end{tabular}

Tabel 7. Scoring penggunaan lahan

\begin{tabular}{lll}
\hline No & Penggunaan lahan & Scoring \\
\hline 1 & Hutan & 4 \\
2 & Kebun, Ladang & 3 \\
3 & Sawah, Semak/belukar & 2 \\
4 & Lahan kosong, & 1 \\
& Pemukiman &
\end{tabular}

Tabel 8. Scoring jumlah penduduk

\begin{tabular}{lll}
\hline No & $\begin{array}{l}\text { Jumlah } \\
\text { penduduk }\end{array}$ & scoring \\
\hline 1 & $0-3.076$ & 4 \\
2 & $3.077-7.672$ & 3 \\
3 & $7.673-13.355$ & 2 \\
4 & $13.356-23.336$ & 1
\end{tabular}

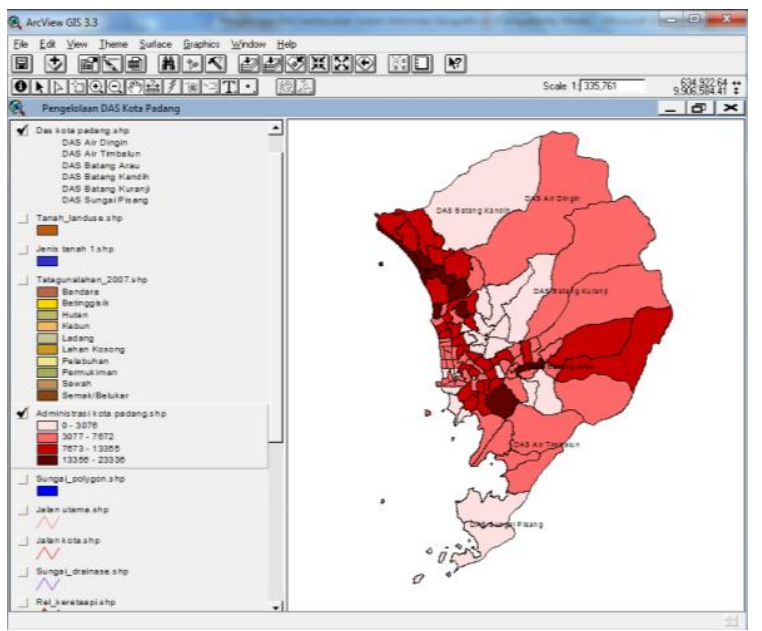

Gambar 6. Penyebaran jumlah penduduk Kota Padang
Tahap berikutnya melakukan overlay terhadap semua data fisik lahan baik secara spasial dan atribut sehingga diperoleh basisdata fisik lahan berupa lereng, jumlah penduduk, penggunaan lahan dan jenis tanah Kota Padang. Untuk mendapatkan informasi kondisi fisik lahan terhadap DAS dan wilayah administrasi selanjutnya dilakukan juga penggabungan terhadap batas DAS dan batasa administrasi kecamatan

Pelaksanaan proses overlay dilakukan dengan memanfaatkan geoprocessing wizard pada perangkat lunak ArcGIS 3.3

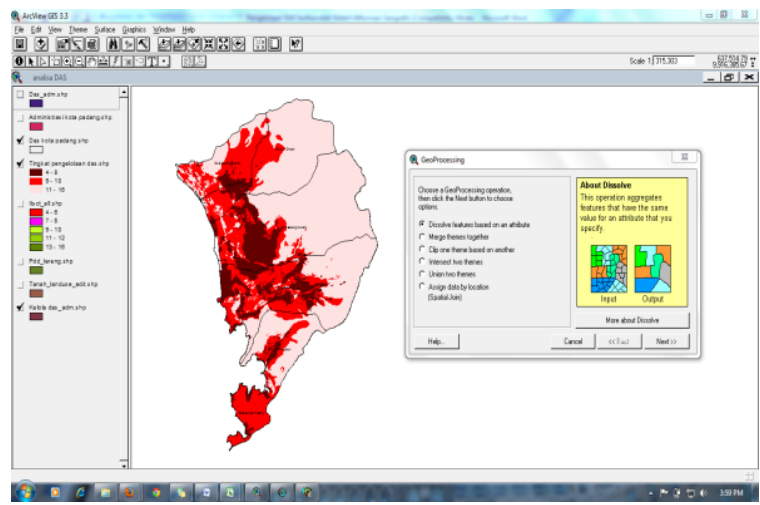

Gambar 7. Geoprocessing wizard

\section{Analisa Pengelolaan DAS}

Analisa pengelolaan DAS didasarkan kepada jumlah dari nilai scoring dari masing masing parameter fisik lahan (lereng, penduduk, penggunaan lahan dan jenis tanah).

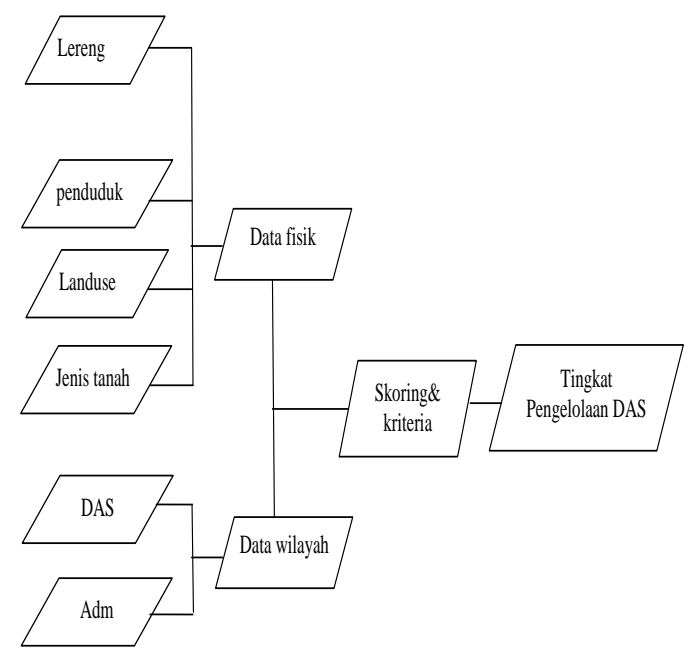

Gambar 8. Tahapan overlay 
Rentang hasil scoring mulai dari angka 4 sampai angka 16. Dengan menggunakan metode natural breaks maka rentang tersebut dibagi menjadi 3 (tiga) kelas

Tingkat pengelolaan DAS berdasarkan jumlah scoring

- Nilai 4-8 dengan tingkat pengelolaan tinggi

- Nilai 9-10 dengan tingkat pengelolaan sedang

- Nilai 11-16 dengan tingkat pengelolaan rendah

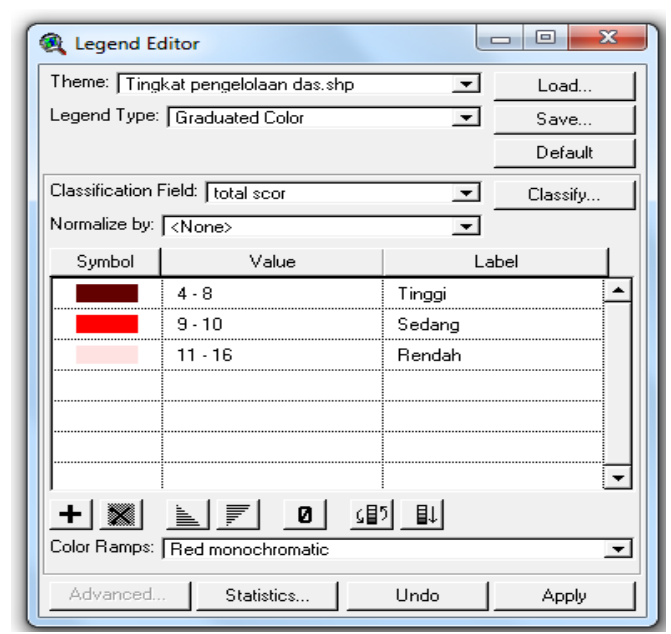

Gambar 9. Klasifikasi hasil scoring

Tingkat pengelolaan tersebut didasarkan kepada prioritas penanganan dan pengelolaan DAS,

Semakin rendah scoring yang diperoleh diharapkan adanya prioritas penanganan tinggi dari DAS yang bersangkutan, demikian juga sebaliknya.

Dari hasil analisa secara spasial dan atribut maka diperoleh DAS Batang Arau dan DAS Batang Kuranji mempunyai tingkat prioritas pengelolaan yang tinggi.

DAS Batang Arau dengan luas 4079,36 Ha meliputi 7 (tujuh) kecamatan dan DAS Batang Kuranji dengan luas 3988,32 meliputi 6 (enam) kecamatan di Kota Padang, seperti yang terlihat pada tabel berikut: 
Tabel 9. Pengelolaan DAS pada tingkatan Tinggi

\begin{tabular}{|c|c|c|c|c|}
\hline No & DAS & Kecamatan & Luas (Ha) & \\
\hline 1 & DAS Air Dingin & $\begin{array}{l}\text { Kec. Koto Tangah } \\
\text { Kec. Bungus Teluk }\end{array}$ & 663.86 & 663.86 \\
\hline 2 & DAS Air Timbalun & Kabung & 533.25 & 533.25 \\
\hline 3 & DAS Batang Arau & $\begin{array}{l}\text { Kec. Kuranji } \\
\text { Kec. Lubuk Begalung } \\
\text { Kec. Lubuk Kilangan } \\
\text { Kec. Padang Barat } \\
\text { Kec. Padang Selatan } \\
\text { Kec. Padang Timur } \\
\text { Kec. Pauh }\end{array}$ & $\begin{array}{r}370.53 \\
660.36 \\
1183.82 \\
498.69 \\
413.77 \\
317.97 \\
634.21\end{array}$ & 4079.36 \\
\hline 4 & $\begin{array}{l}\text { DAS Batang } \\
\text { Kandih } \\
\text { DAS Batang }\end{array}$ & Kec. Koto Tangah & 469.17 & 469.17 \\
\hline 5 & DAS Sungai & $\begin{array}{l}\text { Kec. Koto Tangah } \\
\text { Kec. Kuranji } \\
\text { Kec. Nanggalo } \\
\text { Kec. Padang Barat } \\
\text { Kec. Padang Utara } \\
\text { Kec. Pauh } \\
\text { Kec. Bungus Teluk }\end{array}$ & $\begin{array}{r}819.34 \\
2896.36 \\
91.68 \\
2.59 \\
74.69 \\
103.65\end{array}$ & 3988.32 \\
\hline 6 & Pisang & Kabung & $\begin{array}{l}351.59 \\
\text { jumlah }\end{array}$ & $\begin{array}{r}351.59 \\
10085.55\end{array}$ \\
\hline
\end{tabular}

Secara spasial juga diperoleh gambaran distribusi dari tingkat pengelolaan DAS tersebut

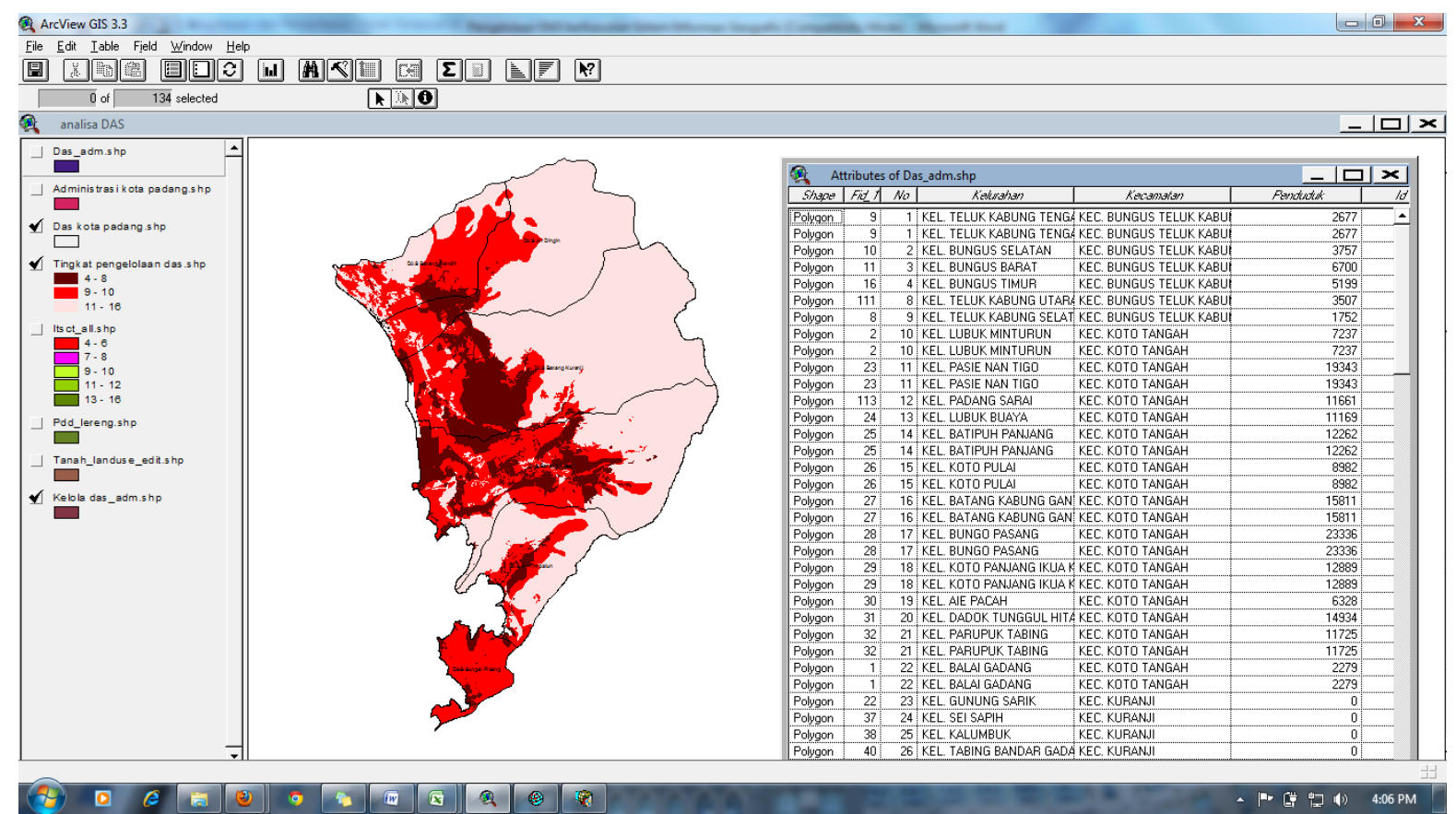

Gambar 10. Tampilan SIG DAS 


\section{SIMPULAN}

Dari penelitian ini didapat kesimpulan sebagai berikut :

1. Sistem informasi geografis mampu menghimpun dan mengelola data-data spasial dan atribut yang berhubungan dengan DAS

2. Sistem informasi Geografis DAS dapat memberikan analisa spasial mengenai tingkat pengelolaan DAS berdasarkan

\section{DAFTAR PUSTAKA}

Daud S. Saribun, 2007. Pengaruh Jenis Penggunaan Lahan Dan Kelas Kemiringan Lereng Terhadap Bobot Isi, Porositas Total, Dan Kadar Air Tanah Pada SubDas Cikapundung Hulu, jurusan Ilmu Tanah Fakultas Pertanian Universitas Padjadjaran Jatinangor.

Balai Pengelolaan DAS Pemali Jratun. Direktorat Jenderal Rlps. Departemen Kehutanan RI. Permasalahan Pengelolaan DAS
Peraturan Direktur Jenderal Bina Pengelolaan Daerah Aliran Sungai Dan Perhutanan Sosial. Nomor : P. 4/VSet/2013.

Tentang Petunjuk Teknis Penyusunan Data Spasial Lahan Kritis.

Fahmudin Agus Dan Widianto. 2004. . Petunjuk Praktik Konservasi Tanah Pertanian Lahan Kering . Bogor: World Agroforestry Centre Icraf Southeast Asia. Hal 6 -7.

Peraturan Pemerintah Republik Indonesia Nomor 37 Tahun 2012 Tentang Pengelolaan Daerah Aliran Sungai.

Prahasta, E. 2001. Konsep-konsep Dasar Sistem Informasi Geografis. Informatika Bandung.

Prahasta, E. 2002. Sistem Informasi Geografis : Tutorial ArcView. Informatika Bandung 